\title{
FTIR Spectroscopic Study of Dolomite From The Central Part of Kaladgi-Badami Basin, Bagalkot District, Karnataka, India
}

\author{
Raju Jayappagol ${ }^{1}$ and A. G. Ugarkar ${ }^{2}$ \\ Department of Studies in Geology, Karnatak University, Dharwad, Karnataka, India-580003 \\ wwwjaps@gmail.com
}

\begin{abstract}
A major part of Bagalkot district, geologically is represented by a thick succession of sedimentary rocks of Kaladgi-Badami basin, which overlies unconformably on a denuded basement comprising Archaean granitoid-greenstone belts. Thick and extensive outcrops of limestone and dolomite associated with shale, phyllite, quartzite, sandstone and conglomerate. The dolomite deposit in the central part near Neeralkeri of Kaladgi-Badami basin occur as massive, compact and bedded rocks invariably associated with limestone. The Dolomite rocks collected in a quarry near Neeralkeri are subjected to mineral analysis. FTIR spectroscopic technique is applied to dolomite samples to identify the principal constituent mineral. From the infrared spectrum, the minerals are identified from the location or band position of peaks with the help of available literature. The mineral dolomite is identified. The performed analyses provided useful information about the mineralogical composition of the carbonate rocks.
\end{abstract}

Keywords- FTIR, Dolomite, Mineral analysis, Kaladgi-Badami basin.

\section{INTRODUCTION}

"Dolomite" a term used for both a mineral and a rock. Dolomite is a widespread, rock-forming, rhombohedral mineral consisting of $\mathrm{CaMg}\left(\mathrm{CO}_{3}\right)_{2}$. Part of the magnesium ions may be substituted for calcium ions. Dolomite is typically colorless or white but may be tinted reddish, brown, yellow, etc. It has perfect cleavage and effervesces feebly in cold, dilute $\mathrm{HCl}$. Dolomite occurs most commonly as a replacement of calcium carbonate minerals. The term is also used for a rock composed predominantly of the mineral dolomite although the term "Dolostone" is preferable [11].

The study area of central part of Kaladgi-Badami Basin where Neeralkeri village lies is in the northern part of Karnataka, in Bagalkot District. It is located to south of the main town of Bagalkot, which covers around $10 \mathrm{~km}$ of it and from Neeralkeri lies $2.5 \mathrm{~km}$ towards SE. the study area lies between N16 $07^{\circ}$ ' $03^{\prime \prime}$ and E75 $42^{\prime}$ ' $21^{\prime \prime}$ and covered in the Survey of India toposheet No. 47P/12. This research work constitutes the results of geological studies carried out around the dolomite deposits of Neeralkeri area of Bagalkot district in northern part of Karnataka. After the limestone in Kaladgi Super Group, dolomite is the most important litho unit of industrial applications. Although KaladgiBadami basin has been studied on its various aspects of geology, Stratigraphy and geodynamics, but attention has not been paid to study of Neeralkeri dolomite deposit of Kaladgi basin. Thus, there is a lacuna in the study of this dolomite; hence the present study deals with the in terms of their FTIR spectroscopic studies, which would serve as an important case study on dolomite deposit of Proterozoic basin of Karnataka.

\section{PREVIOUS WORK}

There exists of good amount of work related to geological setting, mineralogy, lithology, stratigraphic correlation aspects of Kaladgi Basin [3, 4, 5, 7, 9, 10, 12 and19]. However, not much work has been carried out on the dolomite deposits of central part of Kaladgi Basin. Annaiah [2] and Raghuveera [15] have given the location, brief geological map dimension, average composition and total reserve of dolomite deposits. Apart from this, there exists no published work on any other aspect of these dolomite deposits.

\section{LOCATION OF STUDY AREA}

The study area lies in the northern part of Karnataka, in Bagalkot district. It is located at and around Neeralkeri village which is $10 \mathrm{~km}$ to the south of main town of Bagalkot. There are two working quarry sites at $2.5 \mathrm{~km}$ towards south east of Neeralkeri village. The study area lies between $\mathrm{N} 16^{\circ} 07^{\prime} 03^{\prime \prime}$ and E75 $42^{\prime} 21^{\prime \prime}$ and is covered in the Survey of India (SOI) toposheet No. 47P/12. The study area is slightly elevated and has flat top hills and low lying areas. The highest and lowest elevations are $616 \mathrm{~m}$ and $540 \mathrm{~m}$ respectively.

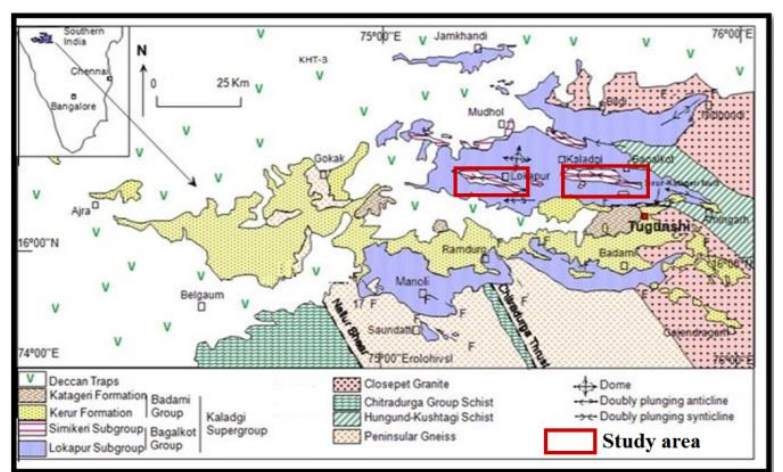

Fig. 1 Geological map of the Kaladgi Basin and study area (modified after [9] [4]).

\section{GEOLOGY}

\subsection{Kaladgi-Badami Basin}

The State of Karnataka comprises mainly Arhcaean Dharwar carton, Proterozoic Kaladgi - Badami basin and Cretaceous Deccan Traps, and younger intrusive of 
dyke swarms. The Kaladgi -Badami basin situated on the northern fringe of the well-known Dharwar craton, consists of a thick succession of sedimentary rocks. These sedimentary rocks overlie on a denuded basement comprising Archaean granitoid-greenstone belts, with an angular unconformity known as Eparchaean unconformity. This basin is disposed E-W for a length of about $160 \mathrm{kms}$ and width varying from 40 to $65 \mathrm{kms}$ and covers an area of about $8000 \mathrm{~km}^{2}$. Kaladgi supergroup is divided into an older Bagalkot Group and a younger Badami Group, separated by a distinct angular unconformity [9].

Bagalkot Group sediments are dominated by arenite, shale, limestone and dolomite with subordinate conglomerate and chert. Structurally, this group displays variable deformation throughout the basin. It is severely deformed along the axial zone of basin and moderate deformation along the basin margins. The Badami Group consists of undeformed horizontal to subhorizontal beds of mainly arenite with subordinate shales and limestones. The Kaladgi-Badami basin has the largest reserves of limestone and dolomite in Karnataka [15].

\subsection{Study area}

The study area shows mostly dolomitic formation generally massive, bedded and is invariably associated with limestone. These dolomites are intervened by many quartz veins, the formations strike in east-west direction and dip towards south and amount of dip is 70o. The dolomite of Neeralkeri area is locally folded and lies on the fold limb. The fold appears to be isoclinals and the fold axis runs in east-west direction. The rocks show jointing and this jointing may have been developed due to folding and along the quartz veins minor faulting is seen. Various erosion and weathering features is also observed in study area. These include elephant skin weathering on the surface. Overall the formations are highly weathered and fractured. The formation appears to be massive, compact, granular and bedded and show large outcrops. The grain size varies as we move towards south. The dolomite varies in shades of grey to light pink and belongs to the lower Kaladgi (Bagalkot Group) basin of Semikeri subgroup of rocks.

\section{MATERIALS AND METHODS}

\subsection{Sample collection}

Fresh twenty samples of dolomite were collected from the study area in sampling bags with labels. Out of twenty, eight samples were collected from M/s. Sangameshwar Dolomite quarry, Neeralkeri. Six samples from M/s Mysore Minerals Ltd, Neeralkeri. Remaining six samples were from M/s Mysore Minerals Ltd, Dolomite quarry, Katageri, Bagalkot district. The collected samples were from various locations covering whole study area while at quarry sites and at depth range of 15-20m (Figure 1). The collected fresh samples were subjected for further processing in the laboratory and later analyzed at University Science and Instrumentation Centre (USIC) of Karnatak University.

\subsection{Sample preparation}

All twenty representative samples were selected for analysis. These were washed with distilled water, and air dried and pulverized in an agate mortar of less than 200 ASTM (American Society for Testing and Materials) mesh. Sample of $2 \mathrm{mg}$ is mixed with $40 \mathrm{mg}$ of spectroscopic $\mathrm{KBr}$ in the ratio 1:20 using a mortar and pestle. Before mixing, necessary amount of $\mathrm{KBr}$ powder is dried at $120^{\circ} \mathrm{C}$ for six hours in an oven. Otherwise the broad spectral peak due to free $\mathrm{OH}$ will seriously affect the interpretation on the bound hydroxyls associated, with any of the minerals. The mineral sample was weighed in a microbalance and placed in a clean agate mortar along with the proper amount of dry $\mathrm{KBr}$ to prepare sample pellet. A pellet of $1 \mathrm{~mm}$ in thickness and $13 \mathrm{~mm}$ in diameter is prepared. A small camel's hair brush is used to transfer the mixture to the die for pressing the pellet. The die is cleaned with water and acetone, and dried before another pellet is prepared. This procedure is followed for the preparation of every pellet. The prepared pellet is preserved in a moisture free glass container before it is placed in a suitable sample holder and introduced in the infrared beam for analysis.

5.3 Sample analysis:

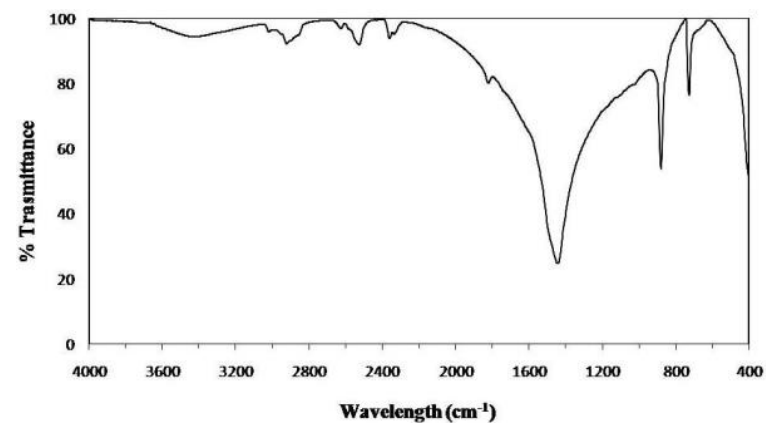

Fig.2. A typical FTIR spectrum of central part of Kaladgi-Badami basin

The Perkin Elmer FTIR Spectrometer available at USIC, Karnatak University, Dharwad, is made use of in the present work for recording the FTIR spectra of the dolomite samples at room temperature. The $\mathrm{KBr}$ pellet technique (1:20) was followed for the mineral analysis. To provide a good characterization of a mineral by infrared spectroscopy, the spectrum has been recorded in the range of $4000-400 \mathrm{~cm}^{-1}$. Such coverage of range ensures that most of the useful vibrations active in the infrared will be included. The instrument scans the spectra 16 times in 1 minute and the resolution is $5 \mathrm{~cm}^{-1}$. This instrument is calibrated for its accuracy with the spectrum of a standard polystyrene film. Every time, before the spectrum of sample is obtained; the spectrum of the polystyrene film is taken and checked for the accuracy and transmittance. The best spectrum for each site was considered as a representative spectrum of the site. The analyzed spectra were interpreted by comparing them with characteristic bands given by [13] The typical FTIR spectrum is shown in Figure 2. 


\section{International Journal of Research in Advent Technology, Vol.7, No.4, April 2019 E-ISSN: 2321-9637 \\ Available online at www.ijrat.org}

\section{RESULTS AND DISCUSSION}

The FTIR spectra of all twenty samples $(60 \mu)$ analyzed were recorded. All the spectra show similar peaks. The typical representative FTIR spectrum is shown in Fig. 2 and the absorption frequencies are presented in Table 1. The present results are in good agreement with the absorption frequencies, reported by Adler et al [1], Ghosh [6] and Russel [18]. The absorption peaks observed in the spectrum indicate the presence of dolomite.

Table.1 Mineralogical composition using FTIR Spectroscopy

\begin{tabular}{|c|c|c|}
\hline $\begin{array}{l}\text { Sl. } \\
\text { No. }\end{array}$ & $\begin{array}{l}\text { Sample } \\
\text { Names }\end{array}$ & IR $\mathrm{cm}^{-1}$ of dolomites \\
\hline 1 & $\mathrm{~A} 2$ & $2527,1441,880,727 \mathrm{~cm}^{-1}$ \\
\hline 2 & A6 & $2526,1439,880,727 \mathrm{~cm}^{-1}$ \\
\hline 3 & A7 & $2631,1438,880,727 \mathrm{~cm}^{-1}$ \\
\hline 4 & B4 & $1439,880,727 \mathrm{~cm}^{-1}$ \\
\hline 5 & B13 & $2628,1441,880,726 \mathrm{~cm}^{-1}$ \\
\hline 6 & B14 & $2634,1440,880,728 \mathrm{~cm}^{-1}$ \\
\hline 7 & B15 & $1440,880,726 \mathrm{~cm}^{-1}$ \\
\hline 8 & B17 & $2634,1438,880,727 \mathrm{~cm}^{-1}$ \\
\hline 9 & $\mathrm{~K} 2$ & $2625,1439,880,727 \mathrm{~cm}^{-1}$ \\
\hline 10 & N1 & $2628,1438,880,727 \mathrm{~cm}^{-1}$ \\
\hline 11 & $\mathrm{R} 4$ & $2628,1440,880,727 \mathrm{~cm}^{-1}$ \\
\hline 12 & R8 & $2628,1441,880,727 \mathrm{~cm}^{-1}$ \\
\hline 13 & S1 & $2624,1442,880,727 \mathrm{~cm}^{-1}$ \\
\hline 14 & $\mathrm{~S} 2$ & $2629,1444,1818,880,727 \mathrm{~cm}^{-1}$ \\
\hline 15 & S3 & $2634,1451,1820,880,727 \mathrm{~cm}^{-1}$ \\
\hline 16 & S4 & $2628,1487,1820,880,727 \mathrm{~cm}^{-1}$ \\
\hline 17 & S5 & $2628,1442,1820,880,727 \mathrm{~cm}^{-1}$ \\
\hline 18 & S6 & $2634,1446,1821,881,727 \mathrm{~cm}^{-1}$ \\
\hline 19 & S7 & $2628,1447,1820,880,728 \mathrm{~cm}^{-1}$ \\
\hline 20 & S8 & $2631,1446,880,727 \mathrm{~cm}^{-1}$ \\
\hline
\end{tabular}

The frequency assignments reported by Herzberg [8] for carbonate minerals are a symmetric stretching, $v_{1}$; an out-of-plane bending, $\quad v_{2} ;$ a doubly degenerate asymmetric stretching, $v_{3}$; and a doubly degenerate planar bending $v_{4}$. But the symmetric oscillation represented by $v_{1}$ is reported to be infrared inactive. These have been recorded for dolomite minerals in the regions of absorption at approximately $1487-1438 \mathrm{~cm}^{-1}$ $\left(v_{3}\right), 881-880 \mathrm{~cm}^{-1}\left(v_{2}\right)$ and $728-726 \mathrm{~cm}^{-1}\left(v_{4}\right)$.

In the present investigation, the spectra showed major proportion having the absorption bands at approximately 1451,880 and $727 \mathrm{~cm}^{-1}$ and minor bands at 1748, $1818-1830,2526,2626$, and $3031 \mathrm{~cm}^{-}$ 1. According to Prost et al [17] and Ramasamy et al [16] the $\mathrm{OH}$ peaks observed at $3424 \mathrm{~cm}^{-1}$ and $2922 \mathrm{~cm}^{-1}$ in spectrum. In dolomite, the carbonate ions retained their planar three fold symmetry, so that the totally symmetric stretching around $1080 \mathrm{~cm}^{-1}\left(v_{1}\right)$ in IR is forbidden, whereas in dolomite, this band is allowed due to the lower symmetry.

The symmetric stretching vibration, $v_{3}$, lying between $1400-1500 \mathrm{~cm}^{-1}$ is particularly interesting, as these vibrations are particularly sensitive to the site symmetry for the carbonate group. As reported by William [20], if the peak is in between this range, the mineral might have been received low pressure during the formation of rock or if the same peak is splitted, one can infer that the mineral received high pressure. In the present case, there is no splitting of $v_{3}$ mode for dolomite, but the peak at around $1440 \mathrm{~cm}^{-1}$ is present within the range $1400-1500 \mathrm{~cm}^{-1}$. This suggests that the mineral received low pressure during the formation of rock. Besides the first order internal modes, the combinational modes $\left(v_{1}+v_{3} ; 2526 \mathrm{~cm}^{-1}\right)$ and $\left(v_{1}+v_{4} ; 1748 \mathrm{~cm}^{-1}\right)$ are also observed with slight variation from sample to sample, which may be due to the impurity content during the formation [14].

\section{CONCLUSION}

Dolomite samples were collected at and around Neeralkeri village of Bagalkot district and subjected to FTIR studies to know its mineralogical constituents. FTIR spectroscopy is a very efficient and useful tool for identification of minerals particularly carbonates rock such as dolomite and calcite. From the mineralogical analysis it was observed/found that dolomite minerals were identified at range of 2624 to $2634 \mathrm{~cm}^{-1}, 1438$ to $1487 \mathrm{~cm}^{-1}, 1818$ to $1821 \mathrm{~cm}^{-1}, 880$ to $881 \mathrm{~cm}^{-1}$ and 726 to $728 \mathrm{~cm}^{-1}$ IR peaks. The study of frequency and vibrational spectra reveals that dolomite minerals received low pressure during the formation of rock, hence in this phase plausibly contains suitable crystallographic environment for the carbonate unit.

\section{ACKNOWLEDGEMENTS}

First author would like to thank Chairman, Department of Studies in Geology, Karnatak University for providing necessary infra-structure and laboratory facilities to carry out this work. Thanks are due to Prof. N. M. Badiger, Director, USIC, Head SAIF program Karnatak University, Dharwad for his help in carrying out FTIR spectroscopic analysis of dolomite samples. We would also like to thank Dr. J. Seetharamappa, Coordinator of SAIF program Karnatak University, Dharwad for his support during the analysis of samples. Thanks are due to Dr. Trivikram Manuvachari for his help in identification of different IR peaks. Thanks are also due to Dr. Ajaykumar N. Asode for his help in preparation of manuscript.

\section{REFERENCES}

[1] Adler. H.H. and Kerr. P.F. "Infrared study of aragonite and calcite". Am. Mineralogist, 47, pp.700-717, 1962.

[2] Annaiah. G. S. and Raghuveera. K.S. "Dolomite deposits of Niralkeri area, Badami taluk, Bijapur district". Dept. of Mines and Geology, Karnataka, Geological Studies, No. 92, 1974.

[3] Chandrashekara Gouda. M. J. and Govinda Rajulu. B. V. "Stromatolite of the Kaladgi basin and their significance in paleoenvironmental studies". Geo.Sur.India, Hyderabad, Miscellaneous Publications, 44, 220-239, 1980. 
[4] Dey. Sukanta, A. K. Rai. and Anjan Chaki. "Palaeoweathering, composition and tectonics of provenance of the Proterozoic intracratonic Kaladgi-Badami basin, Karnataka, southern India: evidence from sandstone petrography and geochemistry". Jour. Asia. Ear. Sci, v.34, pp. 703$715,2009$.

[5] Foote. R.B. "Geology of the Southern Mahratta country”. Mem. Geol. Surv. India, v.12, Pt.1, 268p, 1876.

[6] Ghosh. S. N. "Infra-red spectra of some selected minerals, rocks and products". Jour. Mater. Sci, 13, pp.1877-1886, 1978.

[7] Hegde. G, Pujar. G.S, Bhimsen. K. and Gokhale. N. W. "The Kaladgi basin: A review. In: Ravindra, B. M. \& Rangnathan, N. (eds) Geo-Karnataka”. Mysore Geological Department, Bangalore centenary Volume, pp. 216-226, 1994.

[8] Herzberg. G. "Molecular spectra and molecular structure II. Infrared and Raman spectra of polyatomic molecules". D Van Nostrand Co., Inc., Newyork, pp.178, 1945.

[9] Jayaprakash. A. V, Sundaram. V, Hans. S. K, and Mishra, R. N. "Geology of the Kaladgi-Bhima basin, Karnataka”. Mem. Geol. Soc. India, No.6, pp. 201-226, 1987.

[10] Jayaprakash. A. V. "Purana basins of Karnataka". Geol. Sur. India, Kolkata, Memoirs, 129, 2007.

[11] Kay. G. M. "North American geosynclines": New York, Geological Society of America (GSA) Memoir 48, pp.143, 1951.

[12] Kale. Vivek S. "Constraints on the evolution of the Purana basins of Peninsular India”. Jour. Geol. Soc. India, v.38, pp.231-252, 1991.

[13] Marel. H.W.Van Der. and Beutelspacher. H. "Atlas of infrared spectroscopy of clay minerals and their admixtures". Elsevier Science Ltd. Amsterdam. Pp. 55-57, 241-248, 1976.

[14] Michael. E. Bottcher, Peer-Lennart, Gehlken, Fraser. and Steele D. "Charecterization of inorganic and biogenic magnesian calcite by fourier transform infrared spectroscopy". Solid State Ionics, pp. 1379-1385, 1997.

[15] Pattabhi Ramaiah. N. R. "Limestone and dolomite resources of Karnataka", Geol. Soc. India, Bangalore, pp. 1, 7-9, 46, 191, 198-199, 2003.

[16] Prost. R, Damemi. A, Huard. E. and Driad. J. “Clay \& Clay Miner”. 37 pp. 464, 1989.

[17] Ramasamy. V, Dheenathayalu. M, Ponnusamy. V, Hemalatha. J. and Presannalakshmi. R. "Depth wise analysis of recently excavated Vellar river sediments through FTIR and XRD studies". Indian Jour. Phys, v.83 (9), pp. 1295-1308, 2003.

[18] Russell. J.D. "Infrared methods-A handbook of determinative methods in clay mineralogy". (Ed. Wilson, M.J.) Blackie and Son Ltd. pp. 133-177, 1987.

[19] Vishwanathaih. "Lithostratigraphy of the Kaladgi and the Badami Groups, Karnataka. The Indian Mineralogist Journal. (18), 122-132, 1968.
[20] William. B. White. "Infrared characterization of water and hydroxyl ion in the basic magnesium carbonate minerals". The American Mineralogist, v.56, 1971. 